\title{
Cellular localization and regulation of receptors and enzymes of the endocannabinoid system in intestinal and systemic inflammation
}

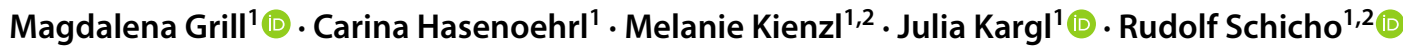

Accepted: 28 August 2018 / Published online: 8 September 2018

(c) The Author(s) 2018

\begin{abstract}
Surveys suggest that Cannabis provides benefit for people with inflammatory bowel disease. However, mechanisms underlying beneficial effects are not clear. We performed in situ hybridization RNAscope ${ }^{\circledR}$ combined with immunohistochemistry to show cell-specific distribution and regulation of cannabinoid receptor 1 and $2\left(C B_{1}, C B_{2}\right), G$ protein-coupled receptor 55 (GPR55), and monoacylglycerol lipase (MGL) mRNA in immune cells using murine models of intestinal and systemic inflammation. In healthy animals, the presence in enteric ganglia is high for $C B_{1}$ mRNA, but low for $C B_{2}$ and $G P R 55$ mRNAs. $M G L$ mRNA is predominant throughout the intestinal wall including myenteric neurons, epithelium, circular and longitudinal muscular layers, and the lamina propria. Within the immune system, B220 $0^{+}$cells exhibit high gene expression for $\mathrm{CB}_{2}$ while the expression of $\mathrm{CB}_{2}$ in $\mathrm{F} 4 / 80^{+}$and $\mathrm{CD}^{+}$cells is less prominent. In contrast, GPR55 mRNA is highly present in $\mathrm{F} 4 / 80^{+}$and $\mathrm{CD}^{+}$cells. qRT-PCR of total colonic segments shows that the expression of GPR55 and MGL genes drops during intestinal inflammation. Also at cellular levels, GPR55 and $M G L$ gene expression is reduced in $\mathrm{F} 4 / 80^{+}$, but not $\mathrm{CD} 3^{+}$ cells. As to systemic inflammation, reduced gene expression of $M G L$ is observed in ileum by qRT-PCR, while at cellular levels, altered gene expression is also seen for $C B_{1}$ and $G P R 55$ in $\mathrm{CD}^{+}$but not $\mathrm{F} 4 / 80^{+}$cells. In summary, our study reveals changes in gene expression of members of the endocannabinoid system in situ attesting particularly GPR55 and MGL a distinct cellular role in the regulation of the immune response to intestinal and systemic inflammation.
\end{abstract}

Keywords Cannabinoid receptors $\cdot \mathrm{GPR} 55 \cdot \mathrm{CB}_{1} \cdot \mathrm{CB}_{2} \cdot \mathrm{MGL} \cdot \mathrm{In}$ situ hybridization

\section{Introduction}

Knowledge of the endocannabinoid system (ECS) has immensely grown in the past few years. Its members, i.e., cannabinoid receptors, endocannabinoids and the enzymes that synthesize/degrade endocannabinoids, have become highly investigated targets [rev. in (Pertwee 2015)]. This molecular network has been recently coined "endocannabinoidome", as

Electronic supplementary material The online version of this article (https://doi.org/10.1007/s00418-018-1719-0) contains supplementary material, which is available to authorized users.

Rudolf Schicho

rudolf.schicho@medunigraz.at

1 Pharmacology Section, Otto Loewi Research Center, Medical University of Graz, Universitätsplatz 4/I, 8010 Graz, Austria

2 BioTechMed Graz, Graz, Austria more components have been added lately (Di Marzo and Piscitelli 2015). Apart from the brain, the gastrointestinal (GI) tract is one of the organs that contains key players of the ECS, including cannabinoid receptors $(\mathrm{CB}) 1$ and $2\left(\mathrm{CB}_{1}, \mathrm{CB}_{2}\right), \mathrm{G}$ protein-coupled receptor 55 (GPR55) and the 2-arachidonoylglycerol (AG)-degrading enzyme monoacylglycerol lipase (MGL) [rev. in (Hasenoehrl et al. 2016)]. Functional tasks of the ECS in the GI tract comprise the control of the epithelial barrier (Cani et al. 2016; Karwad et al. 2017), the maintenance of immune homeostasis (Acharya et al. 2017), the regulation of motility, and the protection against inflammatory attacks (Schicho and Storr 2010). However, a clear understanding of how the ECS is regulated and which cell populations express these molecules during disease in situ is lacking. The GI tract is a heterogeneous organ, and therefore, accommodates the ECS in various cell types. $\mathrm{CB}_{1}$ and $\mathrm{CB}_{2}$ receptors, for instance, have been reported in the enteric nervous system and in epithelial and lamina propria cells (Wright et al. 2005, 2008). GPR55 has been located in enteric neurons and the colonic 
mucosa (Li et al. 2013). A recent study reported that GPR55 is involved in intraepithelial lymphocyte migration (Sumida et al. 2017). Little is known, however, about the cellular localization of GPR55 in the adaptive and innate immune system of the inflamed gut.

Much of the research progress on the ECS is hampered by a lack of specific tools, especially of antibodies against GPR55 and $\mathrm{CB}_{2}$, to detect their localization in different cell populations of the gut. As shown in several reports, antibodies against the $\mathrm{CB}_{2}$ receptor are likely unspecific (Baek et al. 2013; Cecyre et al. 2014; Marchalant et al. 2014). Commercially available antibodies against $\mathrm{CB}_{1}$ have also been evaluated, showing that unspecific staining may be an issue with $\mathrm{CB}_{1}$ antibodies as well (Grimsey et al. 2008). In intestinal tissue, commercially available GPR55 antibodies have been used for immunohistochemistry with more or less strict controls (Galiazzo et al. 2018; Li et al. 2013; Lin et al. 2011). However, most of them show a band in GPR $55^{-/-}$mice at the right molecular weight (see online resource Fig. 1). The strongest indication for antibody specificity, therefore, is the absence of staining in the respective knockout mouse.

In this context, in situ hybridization (ISH) has proved to be a most valuable and highly specific alternative to demonstrate the presence and regulation of $\mathrm{CB}$ receptors $(\mathrm{Li}$ and Kim 2015). As PCR analysis of whole intestinal tissue does not reveal in which cells CB receptor regulation occurs, ISH can be combined with immunohistochemistry (IHC) in colocalization studies to identify the cells in which regulation of receptors takes place. We, therefore, localized and evaluated $C B_{1}, C B_{2}, G P R 55$ and $M G L$ gene expression (the official symbols of encoding genes are termed $\mathrm{Cnrl}, \mathrm{Cnr} 2, \mathrm{Gpr} 55$ and $\mathrm{Mgll}$ ) in mouse models of intestinal and systemic inflammation by a novel ISH technique (RNAscope ${ }^{\circledR}$ ) with emphasis on the localization of GPR55. For co-localization with distinct immune cell populations, we used established T-cell, B-cell and macrophage markers. Intestinal inflammation in mice was induced by adding $2.5 \%$ dextran sulfate sodium (DSS) to the drinking water. DSS disrupts the epithelial barrier in the colon causing inflammation reminiscent of human ulcerative colitis (Eichele and Kharbanda 2017). Systemic inflammation was performed by treatment with lipopolysaccharide (LPS), a model that leads to intestinal barrier dysfunction (Han et al. 2004; Kimura et al. 1997), epithelial injury and a change in T cell populations (Liu et al. 2009). The specificity of the probes was tested in sections of the respective knockout mice $\left(\mathrm{CB}_{1}{ }^{-/}\right.$, $\mathrm{CB}_{2}{ }^{-/-}$, GPR55 $5^{-/-}$, and $\mathrm{MGL}^{-/-}$).

\section{Materials and methods}

\section{Animals}

C57BL/6 mice obtained from Charles River (Sulzfeld, Germany) were used for the experiments. $\mathrm{CB}_{1}^{-1-}$ and $\mathrm{MGL}^{-1-}$ mice were kindly provided by A. Zimmer and R. Zimmermann, respectively (Hasenoehrl et al. 2018; Taschler et al. 2011). $\mathrm{CB}_{2}{ }^{-1-}$ mice were purchased from Jackson Laboratory (Bar Harbor, ME, USA) and GPR55 ${ }^{-/-}$animals from the Mutant Mouse Resource \& Research Center (MMRRC; University of North Carolina, Chapel Hill, NC; USA) (Hasenoehrl et al. 2018). Knockout mice with a C57BL/6 background served as negative controls for ISH and IHC. All mice were bred in our own facilities and housed in plastic cages with sawdust floors at constant temperature $\left(22^{\circ} \mathrm{C}\right)$ under a $12 \mathrm{~h} \mathrm{light} / 12 \mathrm{~h}$ dark cycle with standard lab food and water ad libitum. The experimental procedures were approved by the Austrian Federal Ministry of Science, Research and Economy (protocol numbers: BMWF- 66.010/0131-WF/V/3b/2014; BMWF-66.010/0044-WF/V/3b/2016) and performed in strict accordance with international guidelines.

\section{Treatment of animals}

\section{DSS-induced intestinal inflammation}

Colitis was induced in C57BL/6 mice by adding 2.5\% DSS (MP Biomedicals, Illkirch, France) to their drinking water for 5 days and animals were killed on day 8 (Stancic et al. 2015).

\section{LPS-induced systemic inflammation}

C57BL/6 mice were treated with an intraperitoneal injection of $0.83 \mathrm{mg} / \mathrm{kg}$ LPS (Farzi et al. 2015) (Sigma, Vienna, Austria) or with PBS alone (vehicle) and killed $4 \mathrm{~h}$ later.

\section{Tissue processing}

Colon (DSS treatment) or ileum (LPS treatment) was harvested and cut in half. One piece of tissue was snap frozen in liquid $\mathrm{N}_{2}$ and stored at $-80{ }^{\circ} \mathrm{C}$ until it was further processed for quantitative reverse transcription-polymerase chain reaction (qRT-PCR), the other half was fixed in acid free phosphate-buffered $10 \%$ formaldehyde solution (Roti ${ }^{\circledR}$-Histofix 10\%; pH 7, stabilized with methanol) for 16-24 $\mathrm{h}$ at room temperature. 


\section{RNA isolation and qRT-PCR}

RNA was extracted from tissue samples using TRIzol (Life Technologies). Samples from DSS-treated animals were purified in an additional step with the "RNA clean up" protocol from the RNeasy kit and subsequently subjected to the Oligotex mRNA Mini Kit (both Qiagen) to remove remaining DSS that could inhibit subsequent qRT-PCR steps. All samples were treated with the DNA Removal Kit DNA-free (Life Technologies) and $2 \mu \mathrm{g}$ of total RNA were reverse transcribed to cDNA using High-Capacity cDNA Reverse Transcription Kit (Applied Biosystems, Carlsbad, USA).

Gene expression of $C B_{1}, C B_{2}, G P R 55$ and $M G L$ was quantified using SsoAdvanced ${ }^{\mathrm{TM}}$ Universal $\mathrm{SYBR}^{\circledR}$ Green Supermix (Bio-Rad, Vienna, Austria). Validated primers were purchased from Bio-Rad and relative gene expression was assessed according to the $2^{-\Delta \Delta C q}$ method.

\section{In situ hybridization (ISH) and immunohistochemistry (IHC)}

Freshly harvested and fixed tissue was further processed for paraffin embedding according to standard procedures. Tissue was cut in $5 \mu \mathrm{m}$ sections, baked at $60{ }^{\circ} \mathrm{C}$ for $1 \mathrm{~h}$, de-waxed and rehydrated.

\section{ISH}

RNAscope ${ }^{\circledR}$ is an advanced ISH method where two adjacent probes (the so-called $\mathrm{ZZ}$ probes) are needed to bind to the target sequence to develop a signal. This method provides the possibility of detecting a low number of mRNAs in peripheral tissue due to a decreased background noise (Wang et al. 2012).

$20 \mathrm{ZZ}$ probes for murine $C B_{1}$ (targeting bases 701-1792 of NM_007726.3), $C B_{2}$ (targeting bases 291-719 of NM_009924.3), GPR55 (targeting bases 2-907 of NM_001033290.2) and $3 \mathrm{ZZ}$ probes for $M G L$ (targeting bases 703-849 of NM_001166251.1) (all purchased from Advanced Cell Diagnostics, ACD, Newark, USA) were used to detect the corresponding mRNAs in murine intestinal or systemic inflammation models. ISH (RNAscope ${ }^{\circledR} 2.5 \mathrm{HD}$ brown or red kit for $C B_{1}, C B_{2}$ and GPR55 and BASEscope ${ }^{\text {TM }}$ red kit for $M G L, \mathrm{ACD}$ ) was performed according to manufacturer's protocol. In brief, tissue sections were treated with $\mathrm{H}_{2} \mathrm{O}_{2}$ for 10 min, target retrieval was performed using the Brown FS3000 food steamer for 15 min, each step followed by washes in $\mathrm{H}_{2} \mathrm{O}$ dest. The next day, sections were digested with Protease Plus (for $C B_{1}, C B_{2}$ and GPR55) or Protease IV $(M G L)$ at $40{ }^{\circ} \mathrm{C}$ for $20 \mathrm{~min}$, washed, followed by incubation with the corresponding probes at $40{ }^{\circ} \mathrm{C}$ for $2 \mathrm{~h}$. The procedure was continued according to the manufacturer's protocol for RNAscope ${ }^{\circledR}$ or BASEscope ${ }^{\mathrm{TM}}$ (ACD). $C B_{1}, C B_{2}, G P R 55$ and $M G L$ were stained using 3,3'-diaminobenzidine (DAB; for brightfield) or FastRed (for brightfield and fluorescence, both dyes provided by ACD). Colonic or ileal sections from treated and untreated C57BL/6 mice and the corresponding knockout controls were put on one slide for comparison.

\section{IHC}

Antibodies against cell markers including CD3, CD4, CD8 and FoxP3 (for T-cell subtypes), F4/80 (for monocytes/macrophages), CD45R-B220 (for B lymphocytes), and neurofilament $\mathrm{H}$ and synaptophysin (for neuronal structures [axons/ synapses]) were used to determine cell types co-localizing with mRNAs (see Table 1).

Tissue sections were blocked in $0.1 \mathrm{M}$ PBS containing $0.3 \%$ Triton X-100 and 5\% goat serum (Sigma-Aldrich/ Merck, Darmstadt, Germany). First antibody in $0.1 \mathrm{M}$ PBS containing $0.3 \%$ Triton $\mathrm{X}-100$ and $1 \%$ goat serum was applied over night at $4{ }^{\circ} \mathrm{C}$, IHC was performed using the Vectastain ${ }^{\circledR}$ ABC kit and Vector ${ }^{\circledR}$ VIP HRP substrate kit (both Vector Laboratories) according to the manufacturer's protocol. Sections were counterstained with 1:5 dilutions of Gill's II Hematoxylin or with Methyl green, washed, dried and mounted with Vectamount mounting medium (Vector Laboratories).

\section{Microscopy}

Brightfield images were taken using a Zeiss Axiophot (100x/1.30 Plan-Neofluar objective with oil immersion; Carl Zeiss AG, Oberkochen, Germany) equipped with a high resolution CCD camera (coolsnap cf from Photometrics ${ }^{\circledR}$, Tuscon, AZ, USA; images: $1392 \times 1040$ pixels; 24 bit) and MCID ${ }^{\mathrm{TM}}$ Analysis software 7.0 (InterFocus Imaging Ltd, Linton, England), or an Olympus BX41 microscope (objectives: 20x/0.75, UPlanSApo; 40x/0.95, UPlanSApo; 100x/1.40, UplanSApo with oil immersion) and an Olympus UC 90 digital camera; images: $1688 \times 1353$ pixel; 24 bit connected with Olympus CellSense ${ }^{\circledR}$ standard 1.17 imaging software (Olympus, Vienna, Austria).

Fluorescence images were taken by an Olympus IX70 (objectives: 10x UPlanFl) connected with an Olympus MT20 light source (150W xenon arc burner) and a Hamamatsu ORCA-ER digital camera $(1344 \times 1024$ pixels; Hamamatsu Photonics K.K., Japan). Olympus xcellence ${ }^{\circledR}$ imaging analysis software 1.1 was used for acquiring images $(1344 \times 1024$ pixels, 24 bit). The following fluorescence filters were used: for Fast Red (U-M41007 cube): DM568, excitation filter 540-560, barrier filter 575-645; for Alexa 488 (modified U-MNIBA cube): DM 505, excitation filter BP470-490, barrier filter BA515-550; for DAPI (Olympus DAPI Filter MT20): DM 409, excitation filter 378/52 (MT20 light source), barrier filter HC Quadband Filter 432. Contrast, 
Table 1 Antibodies used in this study

\begin{tabular}{|c|c|c|c|c|}
\hline Antigen/antibody (clone/cat no) & Provider & Specificity shown by & Dilution & Host/isotype \\
\hline CD3 (ab5690) & Abcam, Cambridge, UK & WB (data sheet) & $1: 1000$ & Rabbit IgG pAb \\
\hline CD4 (EPR19514/ ab183685) & Abcam, Cambridge, UK & WB, IP (data sheet) & $1: 1000$ & Rabbit IgG mAb \\
\hline CD8 (ab203035) & Abcam, Cambridge, UK & WB (data sheet) & $1: 2000$ & Rabbit IgG pAb \\
\hline FoxP3 (D6O8R/ \#12653) & $\begin{array}{l}\text { Cell Signaling Technology, Dan- } \\
\text { vers, MA, USA }\end{array}$ & Flow cytometry (data sheet) & $1: 200$ & Rabbit IgG mAb \\
\hline F4/80 (BM8/ sc-52664) & $\begin{array}{l}\text { Santa Cruz Biotechnologies, Dal- } \\
\text { las, TX, USA }\end{array}$ & $\begin{array}{l}\text { Comparison to CD68 (Shi 2010), } \\
\text { data sheet reference) }\end{array}$ & $1: 200$ & Rat IgG2a, mAb \\
\hline $\begin{array}{l}\text { CD45R-B220 (RA3-6B2/ } \\
\text { 14-0452-82) }\end{array}$ & $\begin{array}{l}\text { Thermo Fisher Scientific, } \\
\text { Waltham, MA, USA }\end{array}$ & Flow cytometry, WB (data sheet) & $1: 250$ & Rat IgG 2a, kappa, mAb \\
\hline Neurofilament H(ab8135) & Abcam, Cambridge, UK & WB (data sheet) & $1: 2000$ & Rabbit IgG, pAb \\
\hline $\begin{array}{l}\text { Synaptophysin (SP11/ MA5- } \\
\text { 14532) }\end{array}$ & $\begin{array}{l}\text { Thermo Fisher Scientific, } \\
\text { Waltham, MA, USA }\end{array}$ & WB (data sheet) & $1: 250$ & Rabbit IgG, mAb \\
\hline Biotinylated anti-rabbit IgG & $\begin{array}{l}\text { Vector laboratories, Burlingame, } \\
\text { CA, USA }\end{array}$ & Omission of primary $\mathrm{Ab}$ & $1: 200$ & Goat IgG \\
\hline $\begin{array}{l}\text { Biotinylated anti-rat IgG (BA- } \\
\text { 9401) }\end{array}$ & $\begin{array}{l}\text { Vector laboratories, Burlingame, } \\
\text { CA, USA }\end{array}$ & Enzyme immunoassay (data sheet) & $1: 200$ & Goat IgG \\
\hline Anti-rabbit Alexa Fluor® 488 & $\begin{array}{l}\text { Thermo Fisher Scientific, } \\
\text { Waltham, MA, USA }\end{array}$ & Omission of primary $\mathrm{Ab}$ & $1: 500$ & Goat IgG \\
\hline
\end{tabular}

$W B$ Western blot, $I P$ immunoprecipitation, $m$ monoclonal, $p$ polyclonal, $A b$ antibody

brightness and color balance of images were adjusted using Corel Photo Paint ${ }^{\circledR}$.

\section{Quantification of ISH gene expression}

Tissues to be compared were mounted on one slide to be processed together for ISH and IHC.

A semi-quantitative histological scoring method was chosen based on ACD scoring criteria for RNAscope ${ }^{\circledR}$ to count and compare gene expression in different cell types and between control and diseased animal tissue. In brief, about 100 cells per tissue/mouse ( 3 mice/ treatment) were evaluated. Only cells with a visible nucleus and a clearly confined cell body were taken into account. Dots in each cell were counted and cells were allocated to one of five groups. Group 0 means no expression, group 1 is $1-3$ dots, group 2 is 4-9 dots or 1 cluster, group 3 is 10-15 dots or few clusters, group 4 is $>15$ dots or many clusters. The columns in the graphs indicate the percentage of cells in each group (sum of all groups per treatment equals $100 \%$ ).

\section{Statistics}

ISH: Data are shown as mean +/- standard error of the mean (SEM) with three mice (ISH) or five-ten mice (qRT-PCR) per experimental group. Statistical analysis was done using GraphPad Prism 5.03 (GraphPad Software, La Jolla, CA,
USA). Cell counts were compared by two-way analysis of variance followed by Bonferroni multiple comparison post hoc analysis. Gene expression was compared by unpaired two-tailed Student's $t$ test. $P$ values $<0.05$ were considered significant and denoted with 1, 2 or 3 asterisks when lower than $0.05,0.01$ or 0.001 , respectively.

\section{Results}

\section{Specificity of the ISH probes}

ISH RNAscope ${ }^{\circledR}$ and ISH/IHC were performed to determine detailed cellular localizations of mRNA and to investigate, if changes in gene expression by DSS and LPS treatment can be detected on a cellular level in situ. To evaluate the kit performance and the quality of the fixed tissue, we first performed ISH RNAscope ${ }^{\circledR}$ using the positive (PPIB) and negative (bacterial dapB) probes provided by the manufacturer. The positive probe produced visible ISH staining on all tissues, while the negative probe showed no ISH staining (not shown). Pretreatment conditions were adjusted to minimize tissue digestion and background while maintaining highest possible positive ISH signal. To confirm the specificity of the target probes, untreated $\mathrm{CB}_{1}{ }^{-/-}, \mathrm{CB}_{2}{ }^{-/-}$, GPR55 $5^{-/-}$and $\mathrm{MGL}^{-1-}$ mice were used and compared to healthy or treated wild type mice. $\mathrm{CB}_{1}, \mathrm{CB}_{2}$ and GPR55 probes, used with the 
standard RNAscope ${ }^{\circledR}$ kit, showed no staining at all or only minimal background staining (see online resource Fig. 2). Initially, all RNAscope ${ }^{\circledR}$ probes were detected using the brown detection kit. To better distinguish between ISH and IHC stainings, we switched to the red detection kit for some selected targets. $M G L$, detected by the highly sensitive red BASEscope ${ }^{\mathrm{TM}}$ kit, resulted in only minimal background staining in the corresponding knockout tissue.

\section{Colon/ DSS-induced colitis}

Localization and extent of $C B_{1}$ gene expression markedly differs from $C B_{2}$ gene expression in the murine colon The regulation of $\mathrm{CB}_{1}$ and $\mathrm{CB}_{2}$ at the cellular level in situ during inflammation is still unexplored and the localization of $\mathrm{CB}_{2}$ receptors in the colon has been conflicting so far. Therefore, $C B_{1}$ and $C B_{2}$ gene expression and localization in healthy and DSS-treated mice was investigated using ISH RNAscope ${ }^{\circledR}$. In healthy tissue, $C B_{1}$ gene expression was prominent in enteric ganglia (Fig. 1a), but was also seen in lymph follicles (Fig. 1b), and in epithelial and lamina propria cells (Fig. 1c). Contrary to $C B_{1}, C B_{2}$ mRNA was heavily expressed in lymph follicles (Fig. 1e) but only marginally in the myenteric plexus (Fig. 1d) and the epithelium (Fig. 1f) of healthy colon. qRT-PCR showed that $C B_{1}$ and $C B_{2}$ mRNA levels were not altered in total tissue of DSS-treated mice (Fig. 2a, b), as compared to healthy animals. Likewise, no differences in $C B_{1}$ and $C B_{2}$ mRNA levels were found on the cellular level using scoring criteria as described in the Methods (data not shown). To investigate if $C B_{1}$ mRNA staining in the muscle layers was of neuronal or muscular origin, we stained for neuronal structures using synaptophysin and neurofilament $\mathrm{H}$ (NFH). Some $C B_{1}$ mRNA co-localized with synaptophysin (Fig. 1g) and $\mathrm{NFH}$ in ganglia (Fig. 1h, i). $C B_{1}$ mRNA was also found in the longitudinal muscle layer and did not co-localize with the neuronal markers (Fig. 1g, arrows), indicating $C B_{1}$ gene expression in the longitudinal muscle cells themselves. $C B_{2}$ mRNA highly co-localized with the B-cell marker B220 ${ }^{+}$ (Fig. 1j). Some $C B_{2}$ gene expression was also found in F4/80 ${ }^{+}$(Fig. 1k) and $\mathrm{CD}^{+}$cells (Fig. 11).

The MGL gene is highly expressed in healthy and to a lesser degree in DSS-treated mice $M G L$ gene expression was found in colonic mucosa, epithelial cells, lamina propria cells, myenteric ganglia and particularly in muscle layers of healthy mice (Fig. 3a-c). In DSS-treated animals, qRTPCR showed that overall MGL gene expression was reduced (Fig. 2c). This reduction was particularly visible in the epi- thelium and the circular muscle layer of ISH-stained colon sections (Fig. 3d). To investigate the source of $M G L \mathrm{mRNA}$ in the muscle layers, we performed double ISH/immunofluorescence with $M G L$ and synaptophysin (Fig. 3e) or NFH (not shown). While little co-localization of $M G L$ mRNA with synaptophysin was detectable (Fig. 3e, arrows), most of the $M G L$ mRNA staining did not overlap with synaptophysin/NFH. To determine the cell type responsible for $M G L$ gene expression in the lamina propria, we co-stained for $M G L / C D 3$ (Fig. 3f) and F4/80 (Fig. 3g, h). While the majority of $\mathrm{CD}^{+}$cells were negative for $M G L$ gene expression, over $80 \%$ of $\mathrm{F} 4 / 80^{+}$cells did express $M G L$ in healthy animals (Fig. 3i).

GPR55 mRNA is present in T-cells and macrophages of healthy murine colon GPR55 gene expression was detected in epithelial cells (Fig. 4a), cells of the lamina propria (Fig. 4b) and lymph follicles (Fig. 4c). GPR55 mRNA was only marginally found in neurons of the myenteric plexus (Fig. 4d). No GPR55 gene expression was found in the muscular layers of the colon (not shown). To further determine the cell type of highly expressing cells in the lamina propria, we costained for T-cell markers and for the monocyte/macrophage marker F4/80 in healthy tissue. The GPR55 gene was highly expressed in $\mathrm{CD}^{+}$(Fig. 4e) and F4/80 ${ }^{+}$cells (Fig. 4i, j). All subpopulations of T-cells were positive for GPR55 mRNA staining, i.e., $\mathrm{CD}^{+}{ }^{+}$(Fig. 4f), FoxP3 ${ }^{+}$T regulatory (Fig. 4g), and $\mathrm{CD}^{+}$cells (Fig. 4h).

MGL and GPR55 gene expression is particularly altered in $\mathrm{F} 4 / 80^{+}$cells of DSS-treated mice According to qRT-PCR, levels of $C B_{1}$ and $C B_{2}$ mRNAs from the entire colon wall did not significantly change in intestinal inflammation, whereas GPR55 and MGL gene expression decreased in DSS-treated versus vehicle-treated mice (Fig. 2c, d). While part of this could be explained due to damaged epithelial cells, we asked whether reduction could have also occurred in immune cells. Interestingly, scoring of GPR55 and $M G L$ gene expression in $\mathrm{CD}^{+}$cells revealed no changes (not shown). However, MGL (Fig. 3h, i) and GPR55 (Fig. 4j, k) clearly showed reduced gene expression in $\mathrm{F} 4 / 80^{+}$cells after DSS treatment as compared to healthy animals ( $M G L$ : Fig. 3g; GPR55: Fig. 4i).

\section{Ileum/LPS-induced systemic inflammation}

$C B_{1}$ gene expression is slightly altered at the cellular level, whereas no changes for $C B_{2}$ gene expression were observed in ileum after LPS treatment High $C B_{1}$ gene expression 

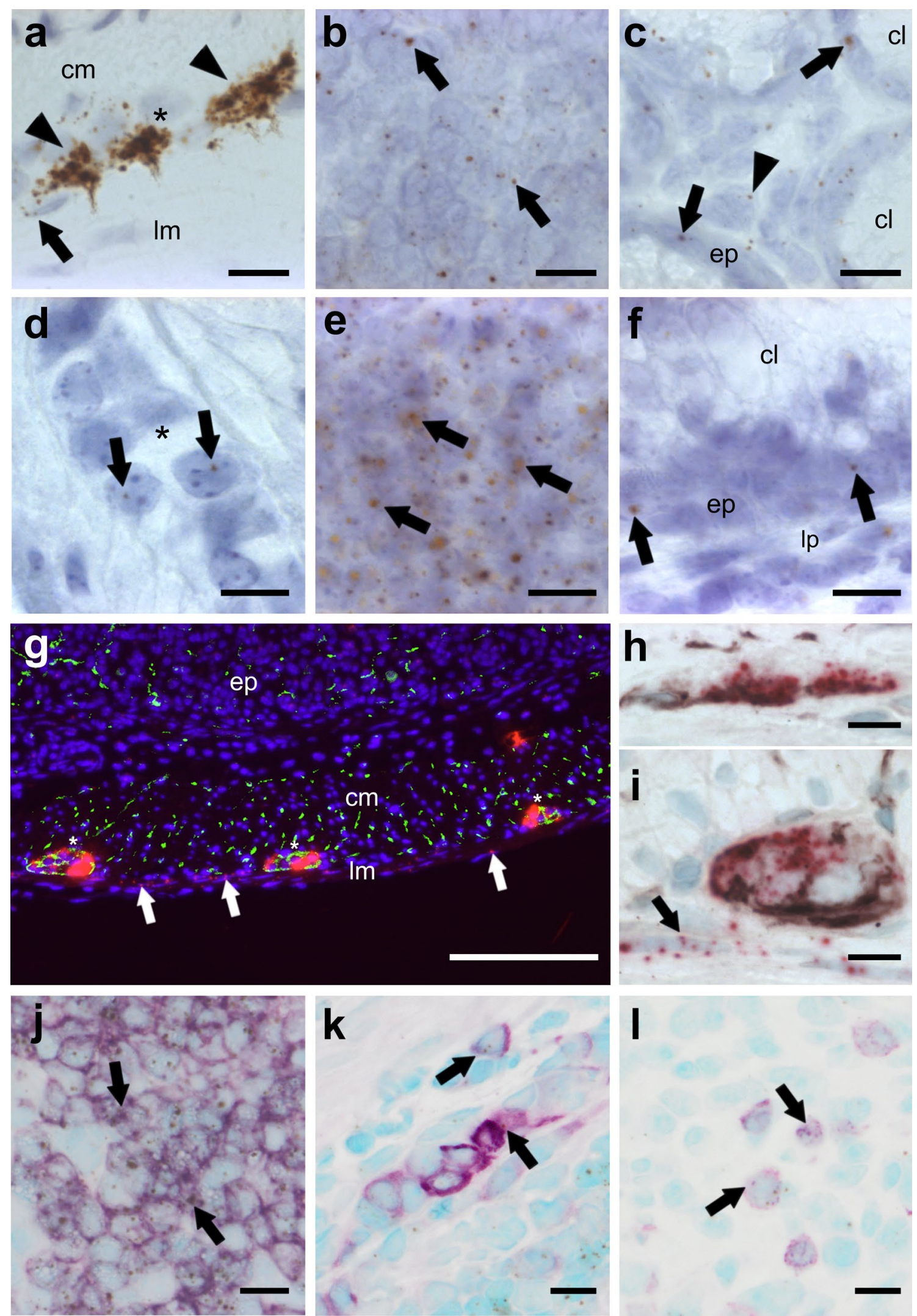
४Fig. 1 ISH staining of $C B_{1}(\mathbf{a}-\mathbf{c}, \mathbf{g}-\mathbf{i})$ and $C B_{2}(\mathbf{d}-\mathbf{f}, \mathbf{j}-\mathbf{l})$ mRNA in the colon of healthy mice. $C B_{1}$ mRNA is strongly detected in neurons of the myenteric (a brown, DAB, arrowheads; i FastRed) and the submucosal plexus (h FastRed). $C B_{1}$ gene expression is also found in the longitudinal muscle layer (a, $\mathbf{g}, \mathbf{i}$ arrows), in lymph follicles (b arrows) and to a lesser degree in epithelial cells (c arrows) as well as some cells of the lamina propria (c, arrowhead). In contrast, $C B_{2}$ gene expression is scarcely found in the myenteric plexus ( $\mathbf{d}$ arrows). Highest expression of the $C B_{2}$ gene occurs in lymph follicles (e arrows), whereas low expression is seen in epithelial cells (f $e p)$ and the lamina propria (f $l p) . C B_{l}$ mRNA fluorescence staining (FastRed) shows modest co-localization (yellow) with synaptophysin (green) in the myenteric plexus (g plexus denoted by asterisks). $C B_{l}$ mRNA (FastRed) shows clear co-localization with neurofilament H (brown, VIP) in the submucosal (h) as well as in the myenteric (i) plexus. $C B_{1}$ mRNA is also found in the longitudinal muscular layer where it does not co-localize with either of the neuronal markers (arrows in $\mathbf{g}$ and $\mathbf{i}$ ). $C B_{2}$ mRNA (brown, DAB) is predominantly detected in $\mathrm{B} 220^{+}$cells (purple, VIP) of lymph follicles (j) and only marginally in $\mathrm{F} 4 / 80^{+}(\mathbf{k})$ or $\mathrm{CD}^{+}(\mathbf{l})$ cells. Calibration bars: $\mathbf{a}-\mathbf{f}, \mathbf{h}-\mathbf{l} 10 \mu \mathrm{m}, \mathbf{g}$ $200 \mu \mathrm{m} ; \mathrm{cm}$ circular muscle layer, $e p$ epithelium, $l p$ lamina propria, lm longitudinal muscle layer, $\mathrm{cl}$ crypt lumen; *, myenteric ganglion; arrows point at representative cells expressing $C B_{1}$ or $C B_{2}$ genes

was detected in the submucosal and the myenteric plexus (Fig. 5a) and in isolated cells of the epithelium, probably neuroendocrine cells (Fig. 5d). Low expression was found in the lamina propria, in lymph follicles, and the rest of the epithelium (Fig. 5b, c). By use of qRT-PCR of total ileal tissue, no differences in $C B_{1}$ RNA levels were found between healthy and LPS-treated animals (Fig. 2e). Only a small amount of $\mathrm{CD}^{+}$cells co-localized with $C B_{1}$ (Fig. 5d, arrows) which was slightly reduced after LPS treatment (Fig. 5e, f). $C B_{2}$ mRNA staining was only marginal in the myenteric plexus (Fig. 6a) but was detectable in lymph follicles co-localizing with $\mathrm{CD}^{+}$, though only with a weak ISH signal (Fig. 6b); however, $C B_{2}$ mRNA was also seen in $\mathrm{CD}^{+}$cells of the lamina propria (Fig. 6d, e) and in $\mathrm{F} 4 / 80^{+}$ cells of healthy (Fig. 6f) and LPS-treated animals (Fig. 6g). No significant differences in $C B_{2}$ gene expression exist between healthy and LPS-treated animals as shown by qRTPCR (Fig. 2f) and by quantification in $\mathrm{CD}^{+}$cells (Fig. 6c).

$M G L$ gene expression is reduced in ileum of LPS-treated mice $M G L$ mRNA staining was detected in the epithelium, lamina propria cells (Fig. 7a, b), myenteric ganglia and the muscle layers (Fig. 7c, d). Total gene expression of $M G L$, as determined by qRT-PCR, was decreased in the ileum of LPS-treated versus healthy animals (Fig. $2 \mathrm{~g}$ ). This corroborates the observation that staining of $M G L$ mRNA in muscle layers is lower in LPS-treated (Fig. 7d) versus healthy mice (Fig. 7c). In addition, $\mathrm{CD}^{+}$cells showed a slight reduction of already low levels of $M G L$ gene expression (Fig. 7e-g). For quantification in $\mathrm{CD}^{+}$cells, see Fig. $7 \mathrm{~g}$. No differences were found between $\mathrm{F} 4 / 80^{+}$cells of healthy (Fig. 7e) and LPS-treated mice (Fig. 7f).

\section{GPR55 mRNA highly co-localizes with T-cell and macrophage markers in the ileum of healthy and LPS-treated mice}

In healthy mice, strong GPR55 mRNA staining was found in the ileal lamina propria (Fig. 8a), crypt epithelial cells (Fig. 8b) and lymph follicles (Fig. 8c). Levels of GPR55 mRNA seemed to be lower in ileal villi (Fig. 8a) than crypts (Fig. 8b). Very low expression was detected in neurons of myenteric ganglia (Fig. 8d). GPR55 ISH was combined with IHC to determine specific immune cells and investigate possible gene expression changes within immune cells. Like in the colon, there was a strong expression of the GPR55 gene in $\mathrm{CD}^{+}$cells (Fig. 8e, f) which could be also detected in all investigated T-cell subpopulations (Fig. 8h-k, n, o) and F4/80 ${ }^{+}$cells (Fig. 81, m).

\section{GPR55 is markedly reduced in $\mathrm{CD}^{+}$cells in LPS-treated mice}

Although qRT-PCR of ileal tissue from LPS-treated mice showed significant expressional changes only for the $M G L$ gene but not for the other genes investigated, the detailed cellular scoring of GPR55 revealed that in contrast to DSSinduced colitis, gene expression of GPR55 in the ileum was lowered in $\mathrm{CD}^{+}$cells (see graph in Fig. 8), but did not change in $\mathrm{F} 4 / 80^{+}$cells (not shown).

\section{Discussion}

Several surveys performed in recent years have indicated that people suffering from inflammatory bowel disease (IBD) are using Cannabis to relieve pain and other symptoms associated with the disease [rev. in (Hasenoehrl et al. 2017)]. A small clinical trial in which Cannabis caused moderate symptom relief in Crohn's patients seems to confirm this (Naftali et al. 2013). Other than these reports, little evidence yet exists whether Cannabis or cannabinoids are protective against IBD in humans. In contrast, a high number of reports describe beneficial effects of cannabinoids in 

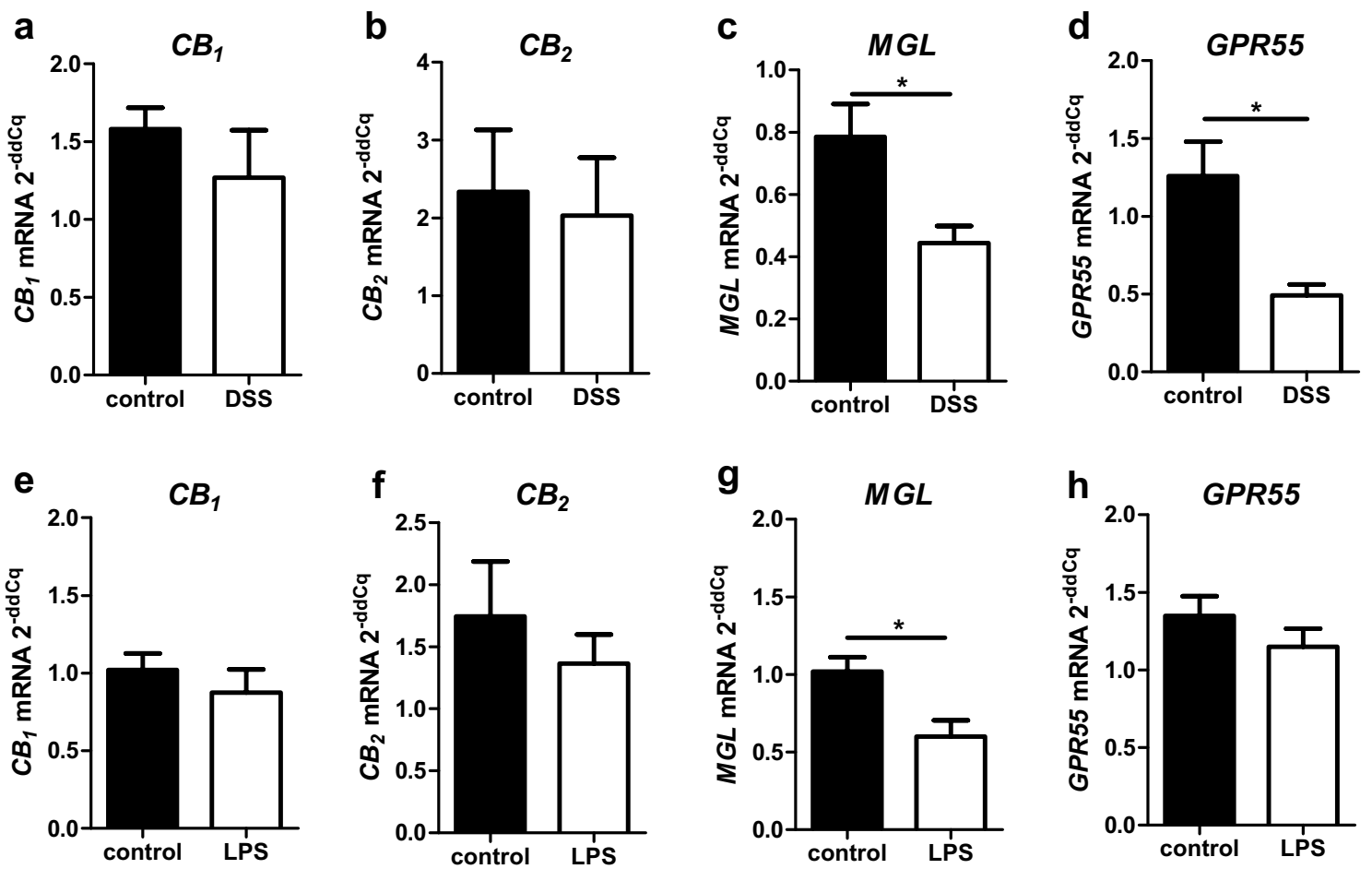

Fig. 2 qRT-PCR evaluation of total mRNA levels of colon (a-d) and ileum (e-h) from healthy and diseased mice. While $C B_{I}$ (a) and $C B_{2}$ (c) gene expression are not significantly altered in mice after DSS treatment, GPR55 (b) and MGL (d) gene expression are significantly

preclinical models of intestinal inflammation [rev. in (Hasenoehrl et al. 2016)].

In our study, we used ISH RNAscope ${ }^{\circledR}$ combined with IHC to identify and quantify gene expression of receptors and enzymes of the ECS in cells of the ileal and colonic wall of mice exposed to DSS and LPS. It is commonly believed that the ECS is an entity that controls homeostasis in the gut and that levels of its receptors are thought to increase during an inflammatory attack. The goal was to measure gene expression of $C B_{1}, C B_{2}, G P R 55$ and $M G L$ and to delineate the cell types responding to the inflammation. The ISH probes against $C B_{1}, C B_{2}, G P R 55$ and $M G L$ were all tested in the respective knockout mouse providing a strong proof for the specificity of the probes, something which is missing for many antibodies used against cannabinoid receptors.

\section{$C B_{1}$ and $C B_{2}$ mRNA in the colon and the ileum}

First, we showed detailed localization of these receptors in the bowel wall, confirming that $\mathrm{CB}_{1}$ is largely present in enteric neurons (Duncan et al. 2005) and only moderately in the epithelial lining. $C B_{1}$ mRNA was also detectable in the longitudinal muscle layer (but hardly in the circular layer)

where it does not co-localize with synaptophysin. Extraneuronal localization of $C B_{1}$ mRNA in the longitudinal muscle layer, therefore, is of interest with regard to a recent article that describes myogenic, besides neurogenic, relaxant effects of $\mathrm{CB}_{1}$ agonists in longitudinal muscle myenteric plexus preparations (LMMP) of the guinea pig (Donnerer and Liebmann 2018). qRT-PCR of whole colonic segments and quantification of $C B_{l} / C B_{2}$ mRNA in single cells of ISH/ IHC stainings revealed little differences between control and DSS- or LPS-treated animals. In the latter, $C B_{1}$ gene expression in $\mathrm{CD}^{+}$cells was even more reduced compared to an already very low expression in healthy mice (Fig. 5f). Although $\mathrm{CB}_{1}$ receptors are important in the regeneration of epithelial cells (Wright et al. 2005), upregulation of $\mathrm{CB}_{1}$ may not be necessary for the regenerative process. It is also possible that a later time point than the one chosen in our experiments might have been more accurate to measure $C B_{1}$ mRNA, as regeneration and re-epithelization after a bout of DSS may take several weeks (Perse and Cerar 2012). A recent study also highlighted that the presence of $\mathrm{CB}_{1}$ in epithelial cells is crucial for the regulation of intestinal permeability (Karwad et al. 2017). However, it is not yet clear how $\mathrm{CB}_{1}$ contributes to permeability during inflammation 

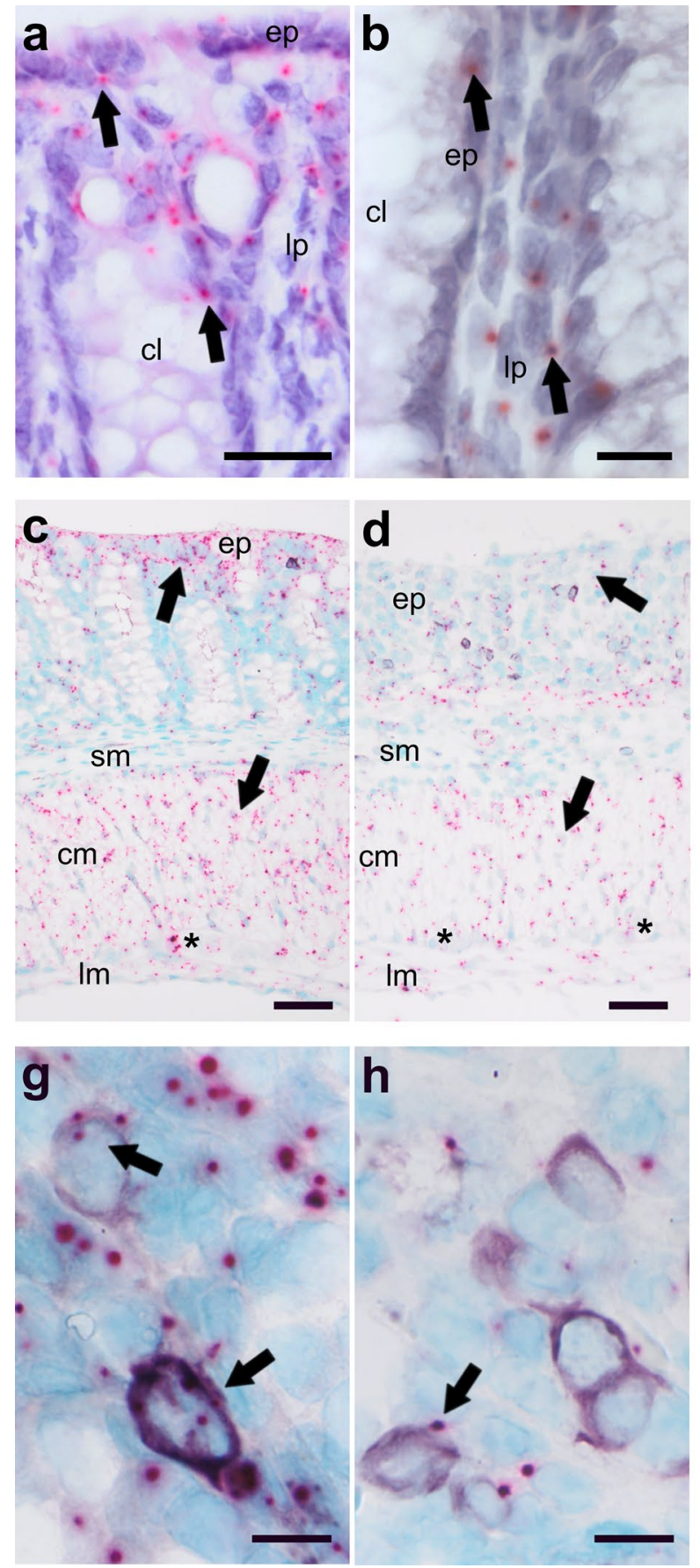

Fig. 3 ISH staining of $M G L$ mRNA in colon of healthy (a-c, e-g) and DSS-treated mice (d, h). MGL mRNA (FastRed) is seen in cells of the epithelium (ep) and the lamina propria $(l p)(\mathbf{a}, \mathbf{b})$, myenteric ganglia (c asterisk), and in the circular $(\mathrm{cm})$ and longitudinal $(\mathrm{lm})$ muscle layer (c) of healthy colonic mucosa. In contrast, $M G L$ gene expression drops throughout the whole colon after DSS treatment, particularly in the epithelium $(e p)$ and the circular muscle layer $(\mathrm{cm})$ (d, arrows). c and $\mathbf{d}$ Taken from ISH/IHC double staining of $M G L$ mRNA (FastRed) and CD3 protein (purple, VIP). Immunofluorescence shows that $M G L$ mRNA (red, FastRed) is abundantly stained in the circular $(\mathrm{cm})$ as well as the longitudinal (lm; arrowheads) muscle layer (e). Co-localization of $M G L$ mRNA with synaptophysin (green, Alexa 488) is rather low (yellow dots; arrows; e). There
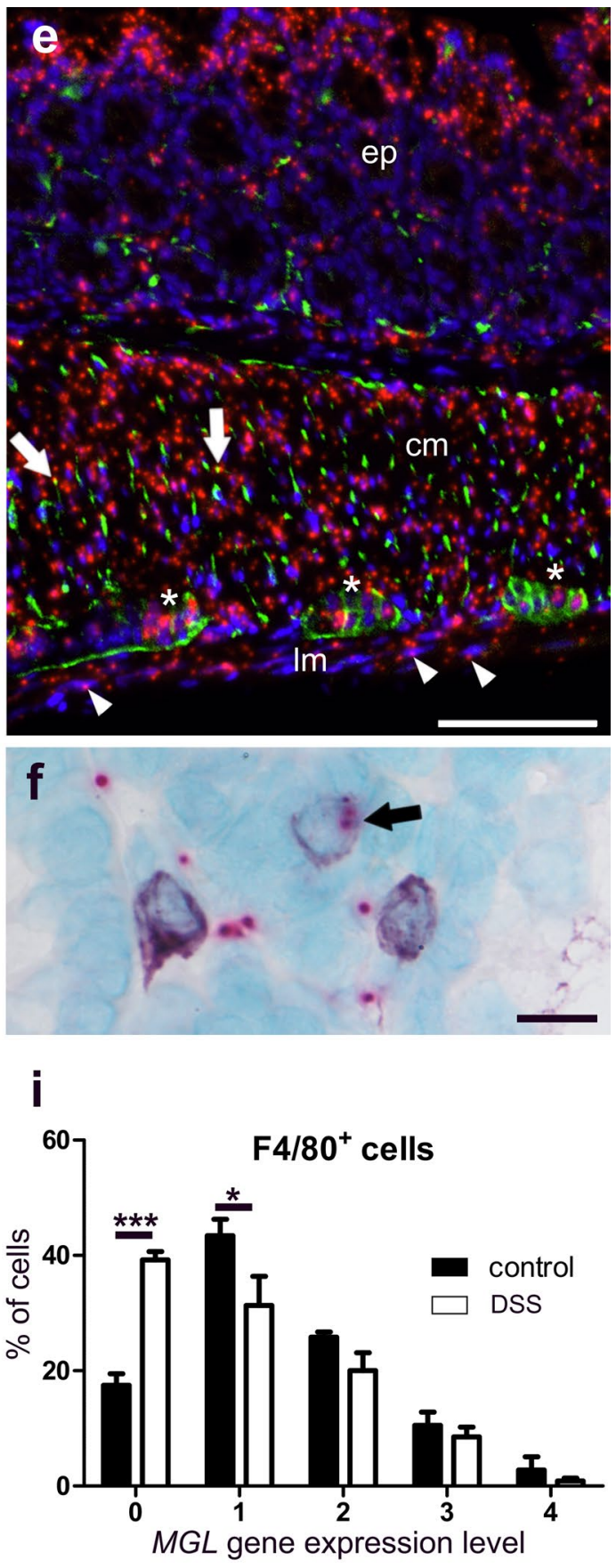

is only little $M G L$ gene expression (pink, FastRed) in $\mathrm{CD}^{+}$cells (purple, VIP) (f). Gene expression of $M G L$ in $\mathrm{F} 4 / 80^{+}$cells (purple, VIP) is decreased after DSS treatment (h) as compared to healthy animals (g). Quantification of $M G L$ mRNA in F4/80 $0^{+}$cells in healthy versus diseased animals is shown in $\mathbf{i}$; note the increased cell number in expression level 0 (no expression) and reduced number of cells in expression level 1. Calibration bar in a $20 \mu \mathrm{m}$; calibration bars in $\mathbf{b}, \mathbf{f}, \mathbf{g}, \mathbf{h} 10 \mu \mathrm{m}$; calibration bars in $\mathbf{c}, \mathbf{d} 50 \mu \mathrm{m}$; calibration bar in $\mathbf{e}$ $100 \mu \mathrm{m} ; \mathrm{cm}$ circular muscle layer, $e p$ epithelium, $l p$ lamina propria, lm longitudinal muscle layer, $c l$ crypt lumen, $s m$ submucosa; *, myenteric ganglia. Arrows point at representative cells expressing $M G L$ mRNA 


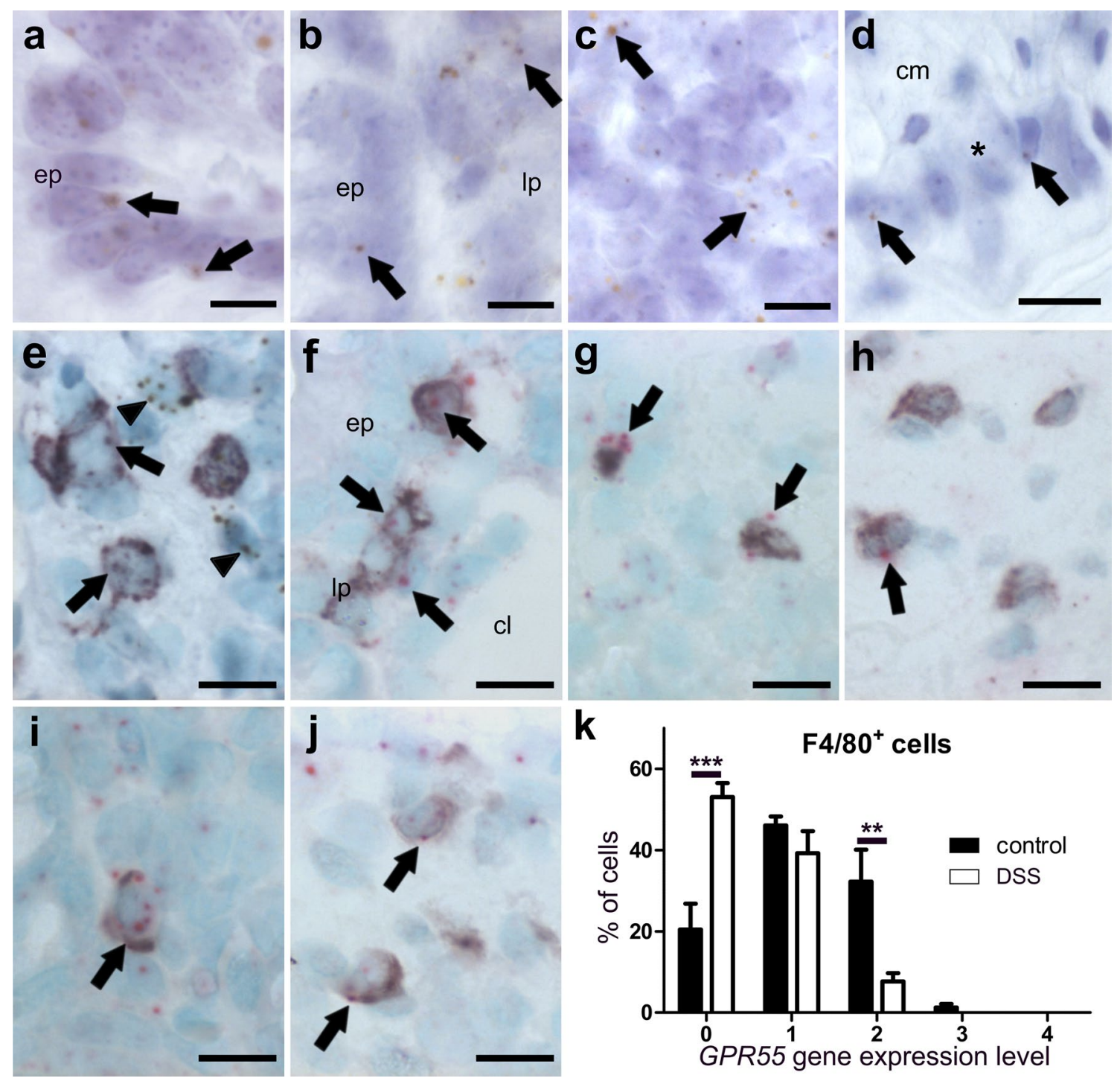

Fig. 4 ISH staining of GPR55 mRNA in colon of healthy (a-i) and DSS-treated mice $(\mathbf{j})$. In the healthy colon, there is moderate expression of the GPR55 gene in epithelial cells $(\mathbf{a}, e p)$, lamina propria cells $(\mathbf{b}, l p)$, lymph follicle $(\mathbf{c})$, and very low expression in myenteric neuronal cells (d brown, DAB; representative GPR55 mRNA staining is denoted by arrows). Co-localization of GPR55 mRNA (brown, DAB) with CD3 (purple, VIP, arrows) in the lamina propria indicates GPR55 gene expression in T-cells although staining is also seen out-

because activation of $\mathrm{CB}_{1}$ by anandamide and 2-AG, applied to the basolateral membrane of Caco-2 cells, have shown opposing effects (Karwad et al. 2017).

The $\mathrm{CB}_{2}$ receptor showed only little gene expression in myenteric neurons and the epithelium of the colon. However, mouse models of colitis show improvement in the presence

side $\mathrm{CD}^{+}$cells (e arrowheads). GPR55 mRNA (FastRed) can be found in all T-cell subpopulations investigated such as in $\mathrm{CD}^{+}(\mathbf{f})$, FoxP $^{+}{ }^{+}$regulatory $(\mathbf{g})$, and $\mathrm{CD} 8^{+}$cells $(\mathbf{h})$. In $\mathrm{F} 4 / 80^{+}$cells, GPR55 mRNA levels are decreased after treatment with DSS (j) as compared to healthy mice (i); the corresponding quantification of cell counts is shown in (k). Calibration bars: $10 \mu \mathrm{m} ; \mathrm{cm}$ circular muscle layer, ep epithelium, $l p$ lamina propria, $l m$ longitudinal muscle layer, $c l$ crypt lumen; *, myenteric ganglion

of $\mathrm{CB}_{2}$ through apoptosis of T-cells (Singh et al. 2012) and through inhibition of the NLRP3 inflammasome in macrophages (Ke et al. 2016). A role in the protection of $\mathrm{CB}_{2}$ expressing immune cells against inflammation is, therefore, quite likely. As observed in the qRT-PCR, the presence of $C B_{2}$ mRNA was not increased in whole bowel wall of the 


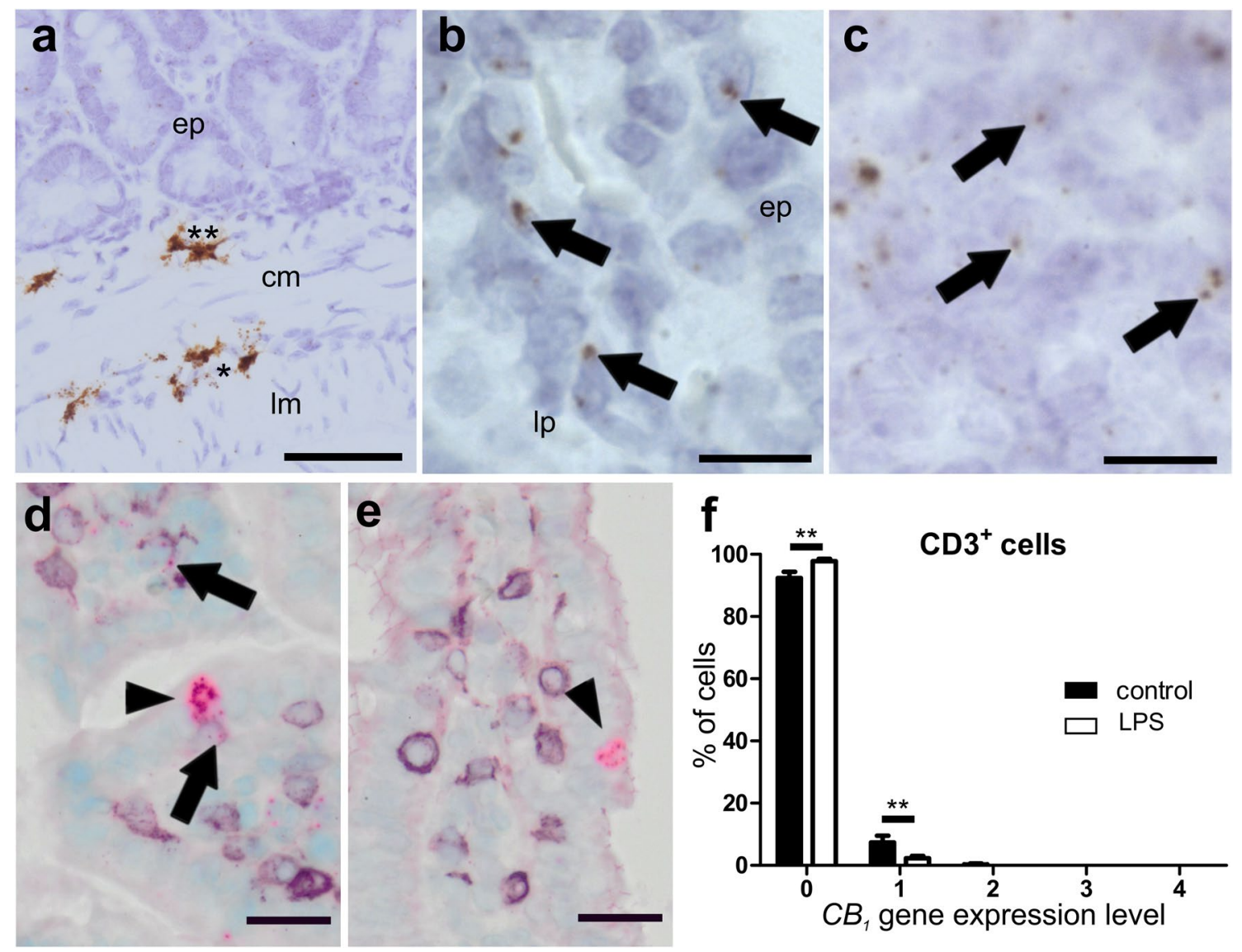

Fig. 5 ISH staining of $C B_{1}$ mRNA in ileum of healthy (a-d) and LPS-treated (e) mice. Strong $C B_{I}$ mRNA ISH staining (brown, DAB) is seen in myenteric (asterisk) and submucosal ganglia (double aster$i s k$ ) in the ileal wall of healthy mice (a). There is only low expression of $C B_{l}$ mRNA (arrows) in the epithelium (b $e p$ ) and the lamina propria $(\mathbf{b} l p)$. High magnification of lymph follicles shows $C B_{1}$ gene expression in healthy animals (c). High levels of $C B_{I}$ mRNA (FastRed) are detected in isolated cells of the epithelium, probably neu- roendocrine cells (arrowheads), from healthy (d) as well as LPStreated (e) mice. Only marginal staining of $C B_{l}$ mRNA is found in $\mathrm{CD}^{+}$cells (d, purple, VIP; arrows) that is even less in the ileum of LPS-treated animals (e). Quantification of $\mathrm{CB}_{1} / \mathrm{CD}^{+}$double staining is shown in $\mathbf{f}$. Calibration bar in $\mathbf{a}: 50 \mu \mathrm{m}$; calibration bar in $\mathbf{b}$, c: $10 \mu \mathrm{m}$; calibration bar in d, e: $20 \mu \mathrm{m} ; \mathrm{cm}$ circular muscle layer, $e p$ epithelium, $l p$ lamina propria, $l m$ longitudinal muscle layer; *, myenteric ganglion; $* *$, submucosal ganglion
DSS and LPS model in comparison with the untreated animals. In contrast, $C B_{2}$ mRNA was described to be upregulated in a TNBS colitis model (Storr et al. 2009). This discrepancy may lie in the different models that were used. Unlike the DSS model, the TNBS colitis model is caused by an immune response to the hapten TNBS, and therefore, differs from the DSS model, which is bacterially driven (Eichele and Kharbanda 2017). It is unclear if and how the strong presence of $\mathrm{CB}_{2}$ in $\mathrm{B}$-cells found in our study could contribute to an amelioration of the inflammation because the presence of T- and B-cells were previously thought not to be needed for the development of acute DSS colitis (Dieleman et al. 1994). However, later studies showed that the
$\mathrm{CB}_{2}$ receptor is critical for the formation of T- and B-cells (Ziring et al. 2006), and also for the homing and retention of marginal zone B lineage cells (Basu et al. 2011). More recent reports have revealed that B cells can protect from DSS colitis in cooperation with Tregs (Wang et al. 2015). $\mathrm{CB}_{2}$ receptors on $\mathrm{B}$ cells, therefore, could participate in the protection against intestinal inflammation.

\section{GPR55 mRNA in the colon and the ileum}

By use of a GPR55 antagonist and GPR55 $5^{-/}$mice, we previously detected a pro-inflammatory role of GPR55 in DSS and TNBS inflammation models (Stancic et al. 2015). In 

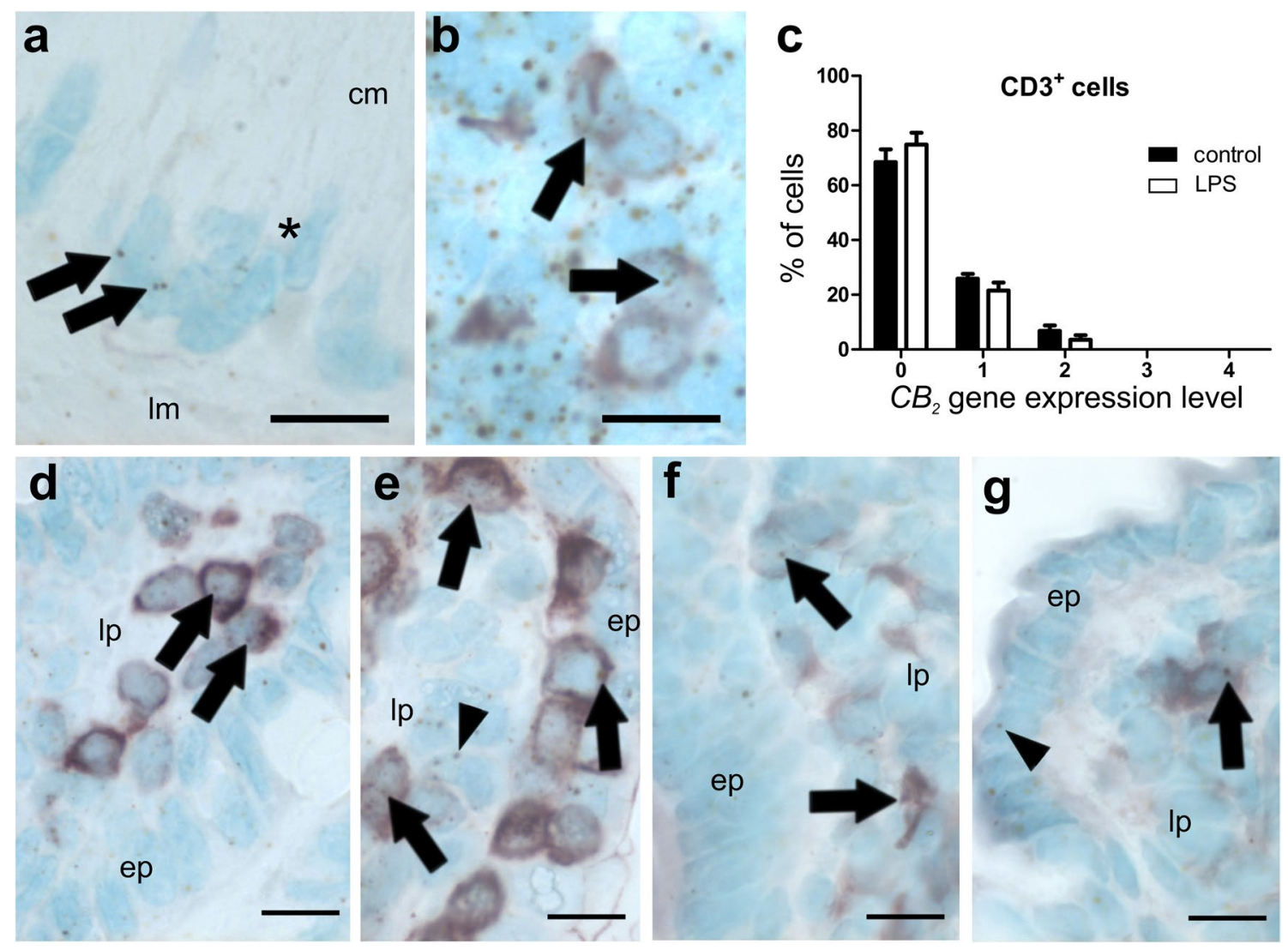

Fig. 6 ISH staining of $C B_{2}$ mRNA in ileum of healthy $(\mathbf{a}, \mathbf{b}, \mathbf{d}, \mathbf{f})$ and LPS-treated $(\mathbf{e}, \mathbf{g})$ mice. Healthy mice show very low gene expression of $C B_{2}$ (brown, DAB) in myenteric ganglia of the ileum (a marked by asterisk; arrows point at mRNA staining). Compared to myenteric ganglia, cells in lymph follicles show widespread $C B_{2}$ gene expression, some located in $\mathrm{CD}^{+}$cells (b arrows). The $\mathrm{CB}_{2}$ gene is also expressed in lamina propria $\mathrm{CD}^{+}$cells of healthy animals, although at a low level (d arrows point at expression in representative cells). Cells often line up underneath the epithelium (ep; e). Also CD3 nega-

the present study, we also focused on GPR55 in immune cells. We observed that mRNA levels of GPR55 in whole colon segments were diminished in DSS mice as compared to controls while in LPS-treated mice, no significant changes were noticed. In line with previous results ( $\mathrm{Li}$ et al. 2013), we also observed that GPR55 mRNA levels were higher in the ileum than in the colon (online resource Fig. 1d). Unlike $C B_{1}, G P R 55$ mRNA showed the prominent presence in epithelial cells, and even more in lamina propria cells, such as macrophages and T-cells. But like $C B_{2}$ (and contrary to $C B_{l}$ ), the GPR55 gene is only little expressed in the myenteric plexus. Most changes, i.e., reductions, in GPR55 gene expression were observed in T-cells during LPS-induced inflammation, while in DSS-induced inflammation, a tive cells expressing the $C B_{2}$ gene are visible In the lamina propria (lp) (e arrowhead). In addition, cells stained for F4/80 show $C B_{2}$ mRNA in healthy (f) and LPS-treated (g) mice. There is only marginal expression of $C B_{2}$ in epithelial cells even after LPS treatment ( $\mathbf{g}$; arrowhead). Quantification of $C B_{2}$ mRNA levels in $\mathrm{CD}^{+}$cells is shown in $\mathbf{c}$, indicating that $C B_{2}$ gene expression is not significantly altered after LPS treatment. Calibration bars: $10 \mu \mathrm{m}$; $e p$ epithelium, lp lamina propria, *, myenteric ganglion

reduction in GPR55 gene expression was predominant rather in $\mathrm{F} 4 / 80^{+}$cells. This is well in line with previous results we obtained in the azoxymethane + DSS cancer model, in which genetic knockout of GPR55 led to a substantially altered T- and myeloid-derived suppressor cell (MDSC) profile when compared to wild-type mice (Hasenoehrl et al. 2018). Additionally, we could previously show that treatment with a GPR55 antagonist leads to reduced influx of lymphocytes and macrophages into the inflamed colon in the DSS model (Stancic et al. 2015). The GPR55 receptor, therefore, seems to primarily act in immune cells during inflammatory attacks in the GI tract. 

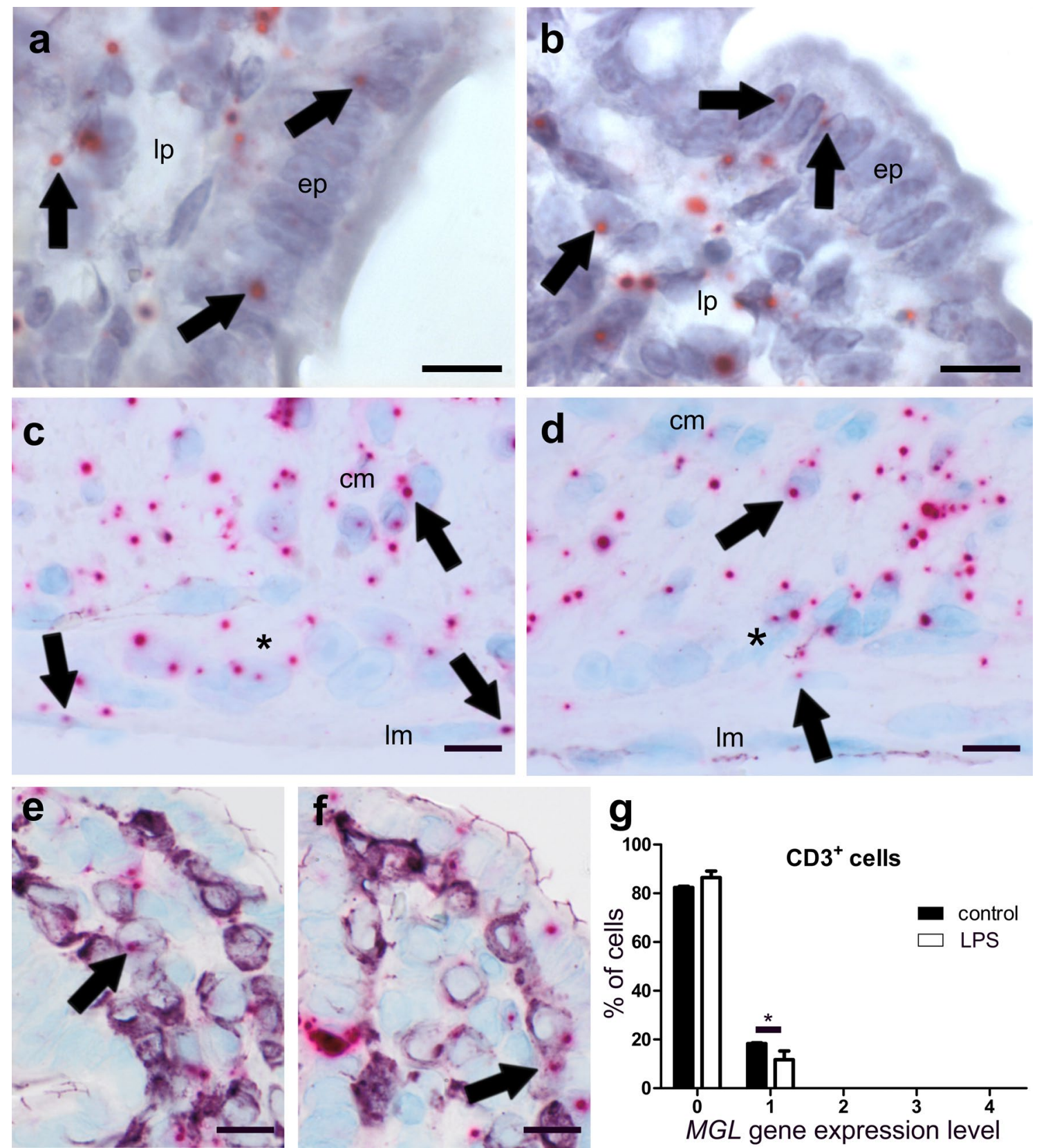

Fig. 7 ISH staining of $M G L$ mRNA (FastRed) in ileum of healthy (a, c, e) and LPS-treated $(\mathbf{b}, \mathbf{d}, \mathbf{f})$ mice. $M G L$ mRNA is equally present in epithelium (ep) and lamina propria ( $l p$ ) cells of healthy ileum (a) and ileum from LPS-treated mice (b arrows denote representative mRNA staining). Expression is also present in myenteric ganglia (denoted by an asterisk) of healthy (c) and LPS-treated (d) mice. Expression of the $M G L$ gene is widespread in the circular $(\mathrm{cm})$ and the longitudinal

\section{Presence of MGL mRNA}

MGL is a key enzyme in the degradation of 2-AG, and therefore, a well characterized member of the ECS (Grabner et al. 2017). Pharmacologic inhibition of MGL has been shown to improve TNBS-induced colitis (Alhouayek et al. 2011). muscle layer $(\operatorname{lm})$, (arrows in $\mathbf{c}$ ), and it is slightly decreased in LPStreated mice (d). Only low co-localization of $M G L$ gene expression with $\mathrm{CD}^{+}$cells (purple, VIP) is found in healthy (e) and even lower co-localization in LPS-treated (f) mice. Quantification of $M G L / C D 3$ double staining is shown in g. Calibration bars: $10 \mu \mathrm{m} ; \mathrm{cm}$ circular muscle layer, $e p$ epithelium, $l p$ lamina propria, $I m$ longitudinal muscle layer, $c l$ crypt lumen; *, myenteric ganglion

Inhibition of MGL also protects from LPS-induced lung injury (Costola-de-Souza et al. 2013). We found that the presence of $M G L$ mRNA was decreased in DSS mice and after LPS treatment, and since MGL inhibition protects from injury, a decrease in MGL in the disease models could very well be part of a protective mechanism. Contrary to previous 

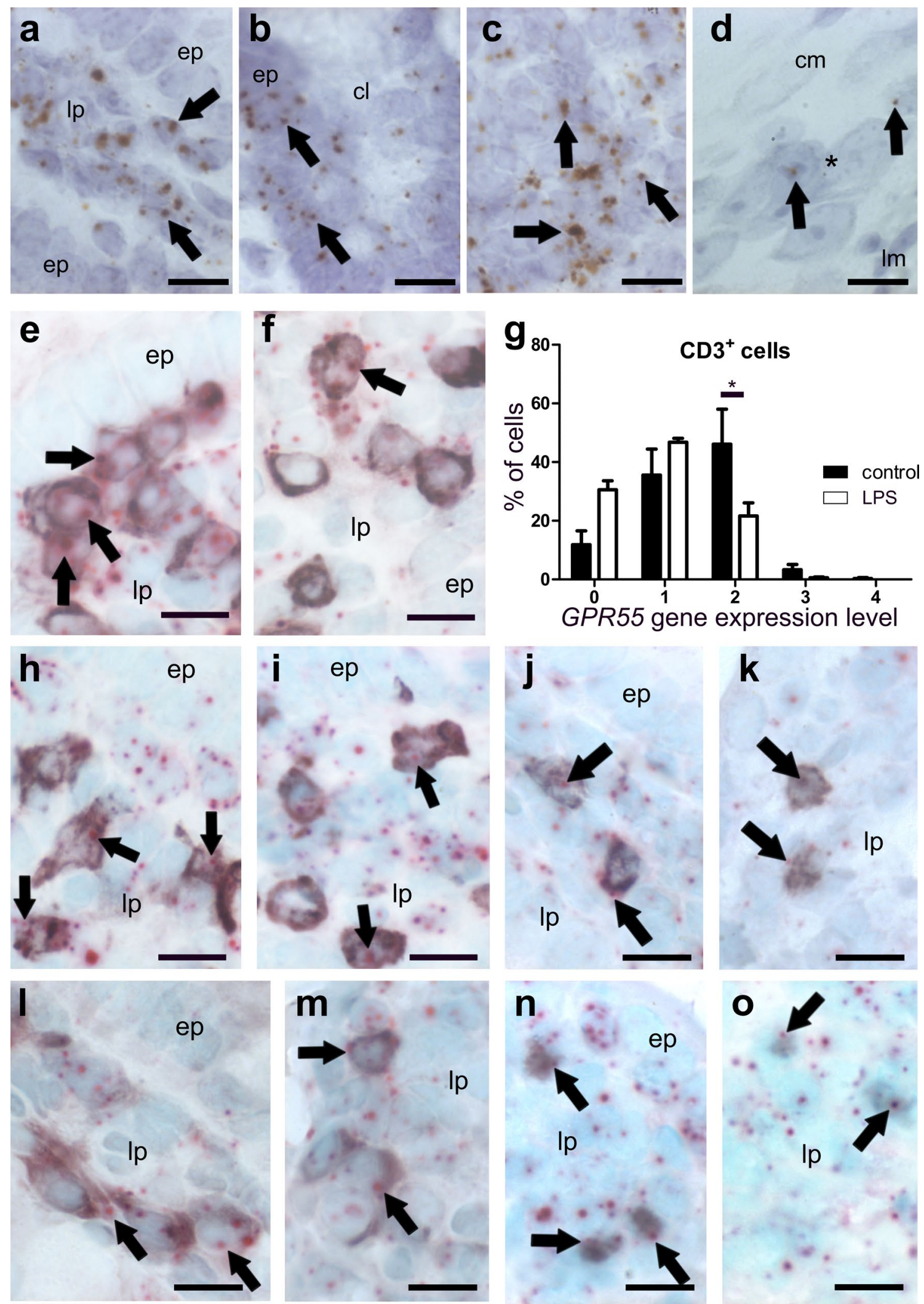
४Fig. 8 ISH staining of GPR55 mRNA (brown, DAB, a-d) and colocalization of GPR55 mRNA (FastRed, e-o) with markers for T-lymphocytes and macrophages (all purple, VIP) in the ileum of healthy (a-d, e, h, $\mathbf{j}, \mathbf{l}, \mathbf{n})$ and LPS-treated mice $(\mathbf{f}, \mathbf{i}, \mathbf{k}, \mathbf{m}, \mathbf{o})$. GPR55 mRNA is predominantly found in the lamina propria of the ileum mucosa (arrows point at representative expression) and in epithelial cells of healthy mice (a, b). Epithelial cells $(e p)$ of villi show low levels of GPR55 mRNA (a), whereas crypt epithelial cells (ep) display relatively strong GPR55 gene expression (b). In healthy animals, strong GPR55 gene expression is detected also in lymph follicles (c), while in myenteric ganglia, expression is low (d; arrows; ganglion denoted by asterisk). GPR55 gene expression appears to be stronger in $\mathrm{CD}^{+}$T-cells of the lamina propria ( $\left.l p\right)$ of the healthy ileum (e) when compared to LPS-treated animals (f). Arrows denote representative staining. Quantification of GPR55 mRNA in $\mathrm{CD}^{+}$cells is shown in $\mathbf{g}$. In the lamina propria of the ileum mucosa, GPR55 gene expression is seen in $\mathrm{CD}^{+}$cells (h, healthy; $\mathbf{i}$, LPS-treated), $\mathrm{CD}^{+}$ cells (j, healthy; $\mathbf{k}$, LPS-treated), F4/80 ${ }^{+}$cells (l, healthy; m, LPStreated), and FoxP3 ${ }^{+} \mathrm{T}$ regulatory cells (n, healthy; o, LPS-treated). Calibration bars: $10 \mu \mathrm{m}$; ep epithelium, $l p$ lamina propria, *, myenteric ganglion; arrows point at representative cells expressing the GPR55 gene

reports (Duncan et al. 2008), we observed $M G L$ gene expression in the smooth muscle layer of the GI tract, indicating that $M G L$ is expressed in smooth muscle cells themselves although the presence in resident macrophages cannot be excluded (Wehner and Engel 2017). However, owing to the abundance of $M G L$ gene expression seen in the longitudinal muscle layer which is devoid of resident macrophages (Wehner and Engel 2017) as well as the observation that most of $M G L$ mRNA does not co-localize with synaptophysin (Fig. 3e), $M G L$ is likely expressed in the smooth myocytes themselves.

To conclude, RNAscope ${ }^{\circledR}$ ISH technique combined with IHC is an extremely valuable method for identifying gene expression and regulation of receptors and enzymes at a single cell basis in situ, as demonstrated by the response of the ECS to intestinal and systemic inflammation. Alterations in the gene expression of GPR55 and $M G L$ in $\mathrm{CD}^{+}$ lymphocytes and $\mathrm{F} 4 / 80^{+}$macrophages indicate that these two components of the ECS are an important part of the innate and adaptive immune response to the inflammatory attack. An upregulation of $C B_{1}$ and $C B_{2}$, often suggested as part of a homeostatic response of the ECS to injury, was not observed.

Acknowledgements Open access funding provided by Medical University of Graz. Thanks to Veronika Pommer for expert technical assistance.

Funding The study was supported by the Austrian Science Fund (P30144 to RS).

\section{Compliance with ethical standards}

Conflict of interest The authors declare that they have no conflicts of interest.
Research involving animal participants All applicable international, national, and/or institutional guidelines for the care and use of animals were followed.

Open Access This article is distributed under the terms of the Creative Commons Attribution 4.0 International License (http://creativeco mmons.org/licenses/by/4.0/), which permits unrestricted use, distribution, and reproduction in any medium, provided you give appropriate credit to the original author(s) and the source, provide a link to the Creative Commons license, and indicate if changes were made.

\section{References}

Acharya N, Penukonda S, Shcheglova T, Hagymasi AT, Basu S, Srivastava PK (2017) Endocannabinoid system acts as a regulator of immune homeostasis in the gut. Proc Natl Acad Sci USA 114:5005-5010

Alhouayek M, Lambert DM, Delzenne NM, Cani PD, Muccioli GG (2011) Increasing endogenous 2-arachidonoylglycerol levels counteracts colitis and related systemic inflammation. FASEB J 25:2711-2721

Baek JH, Darlington CL, Smith PF, Ashton JC (2013) Antibody testing for brain immunohistochemistry: brain immunolabeling for the cannabinoid $\mathrm{CB}(2)$ receptor. J Neurosci Methods 216:87-95

Basu S, Ray A, Dittel BN (2011) Cannabinoid receptor 2 is critical for the homing and retention of marginal zone B lineage cells and for efficient T-independent immune responses. J Immunol 187:5720-5732

Cani PD, Plovier H, Van Hul M, Geurts L, Delzenne NM, Druart C, Everard A (2016) Endocannabinoids-at the crossroads between the gut microbiota and host metabolism. Nat Rev Endocrinol 12:133-143

Cecyre B, Thomas S, Ptito M, Casanova C, Bouchard JF (2014) Evaluation of the specificity of antibodies raised against cannabinoid receptor type 2 in the mouse retina. Naunyn Schmiedebergs Arch Pharmacol 387:175-184

Costola-de-Souza C, Ribeiro A, Ferraz-de-Paula V, Calefi AS, Aloia TP, Gimenes-Junior JA, de Almeida VI, Pinheiro ML, PalermoNeto J (2013) Monoacylglycerol lipase (MAGL) inhibition attenuates acute lung injury in mice. PLoS One 8:e77706

Di Marzo V, Piscitelli F (2015) The endocannabinoid system and its modulation by phytocannabinoids. Neurotherapeutics 12:692-698

Dieleman LA, Ridwan BU, Tennyson GS, Beagley KW, Bucy RP, Elson CO (1994) Dextran sulfate sodium-induced colitis occurs in severe combined immunodeficient mice. Gastroenterology 107:1643-1652

Donnerer J, Liebmann I (2018) Effect of CB1 Ligands on Neurogenic and Myogenic Contractile Responses in the Guinea-Pig Ileum. Pharmacology 101:330-336

Duncan M, Davison JS, Sharkey KA (2005) Review article: endocannabinoids and their receptors in the enteric nervous system. Aliment Pharmacol Ther 22:667-683

Duncan M, Thomas AD, Cluny NL, Patel A, Patel KD, Lutz B, Piomelli D, Alexander SP, Sharkey KA (2008) Distribution and function of monoacylglycerol lipase in the gastrointestinal tract. Am J Physiol Gastrointest Liver Physiol 295:G1255-G1265

Eichele DD, Kharbanda KK (2017) Dextran sodium sulfate colitis murine model: An indispensable tool for advancing our understanding of inflammatory bowel diseases pathogenesis. World $\mathrm{J}$ Gastroenterol 23:6016-6029

Farzi A, Reichmann F, Meinitzer A, Mayerhofer R, Jain P, Hassan AM, Frohlich EE, Wagner K, Painsipp E, Rinner B, Holzer P (2015) Synergistic effects of NOD1 or NOD2 and TLR4 activation on 
mouse sickness behavior in relation to immune and brain activity markers. Brain Behav Immun 44:106-120

Galiazzo G, Giancola F, Stanzani A, Fracassi F, Bernardini C, Forni M, Pietra M, Chiocchetti R (2018) Localization of cannabinoid receptors CB1, CB2, GPR55, and PPARalpha in the canine gastrointestinal tract. Histochem Cell Biol 150:187-205. https://doi. org/10.1007/s00418-018-1684-7

Grabner GF, Zimmermann R, Schicho R, Taschler U (2017) Monoglyceride lipase as a drug target: At the crossroads of arachidonic acid metabolism and endocannabinoid signaling. Pharmacol Ther 175:35-46

Grimsey NL, Goodfellow CE, Scotter EL, Dowie MJ, Glass M, Graham ES (2008) Specific detection of CB1 receptors; cannabinoid CB1 receptor antibodies are not all created equal! J Neurosci Methods 171:78-86

Han X, Fink MP, Yang R, Delude RL (2004) Increased iNOS activity is essential for intestinal epithelial tight junction dysfunction in endotoxemic mice. Shock 21:261-270

Hasenoehrl C, Taschler U, Storr M, Schicho R (2016) The gastrointestinal tract - a central organ of cannabinoid signaling in health and disease. Neurogastroenterol Motil 28:1765-1780

Hasenoehrl C, Storr M, Schicho R (2017) Cannabinoids for treating inflammatory bowel diseases: where are we and where do we go? Expert Rev Gastroenterol Hepatol 11:329-337

Hasenoehrl C, Feuersinger D, Sturm EM, Barnthaler T, Heitzer E, Graf R, Grill M, Pichler M, Beck S, Butcher L, Thomas D, Ferreiros N, Schuligoi R, Schweiger C, Haybaeck J, Schicho R (2018) G protein-coupled receptor GPR55 promotes colorectal cancer and has opposing effects to cannabinoid receptor 1 . Int J Cancer 142:121-132

Karwad MA, Couch DG, Theophilidou E, Sarmad S, Barrett DA, Larvin M, Wright KL, Lund JN, O'Sullivan SE (2017) The role of CB1 in intestinal permeability and inflammation. FASEB J $31: 3267-3277$

Ke P, Shao BZ, Xu ZQ, Wei W, Han BZ, Chen XW, Su DF, Liu C (2016) Activation of cannabinoid receptor 2 ameliorates DSSinduced colitis through inhibiting NLRP3 inflammasome in macrophages. PLoS One 11:e0155076

Kimura H, Sawada N, Tobioka H, Isomura H, Kokai Y, Hirata K, Mori M (1997) Bacterial lipopolysaccharide reduced intestinal barrier function and altered localization of 7H6 antigen in IEC-6 rat intestinal crypt cells. J Cell Physiol 171:284-290

Li Y, Kim J (2015) Neuronal expression of CB2 cannabinoid receptor mRNAs in the mouse hippocampus. Neuroscience 311:253-267

Li K, Fichna J, Schicho R, Saur D, Bashashati M, Mackie K, Li Y, Zimmer A, Goke B, Sharkey KA, Storr M (2013) A role for O-1602 and G protein-coupled receptor GPR55 in the control of colonic motility in mice. Neuropharmacology 71:255-263

Lin XH, Yuece B, Li YY, Feng YJ, Feng JY, Yu LY, Li K, Li YN, Storr M (2011) A novel CB receptor GPR55 and its ligands are involved in regulation of gut movement in rodents. Neurogastroenterol Motil 23:862

Liu C, Li A, Weng YB, Duan ML, Wang BE, Zhang SW (2009) Changes in intestinal mucosal immune barrier in rats with endotoxemia. World J Gastroenterol 15:5843-5850

Marchalant Y, Brownjohn PW, Bonnet A, Kleffmann T, Ashton JC (2014) Validating Antibodies to the Cannabinoid CB2 Receptor: Antibody Sensitivity Is Not Evidence of Antibody Specificity. J Histochem Cytochem 62:395-404
Naftali T, Bar-Lev Schleider L, Dotan I, Lansky EP, Sklerovsky Benjaminov F, Konikoff FM (2013) Cannabis induces a clinical response in patients with Crohn's disease: a prospective placebo-controlled study. Clin Gastroenterol Hepatol 11:12761280.e1

Perse M, Cerar A (2012) Dextran sodium sulphate colitis mouse model: traps and tricks. J Biomed Biotechnol 2012:718617

Pertwee RG (2015) Endocannabinoids and Their Pharmacological Actions. Handb Exp Pharmacol 231:1-37

Schicho R, Storr M (2010) Targeting the endocannabinoid system for gastrointestinal diseases: future therapeutic strategies. Expert Rev Clin Pharmacol 3:193-207

Shi X (2010) Resident macrophages in the cochlear blood-labyrinth barrier and their renewal via migration of bone-marrow-derived cells. Cell Tissue Res 342:21-30

Singh UP, Singh NP, Singh B, Price RL, Nagarkatti M, Nagarkatti PS (2012) Cannabinoid receptor-2 (CB2) agonist ameliorates colitis in IL-10(-l-) mice by attenuating the activation of T cells and promoting their apoptosis. Toxicol Appl Pharmacol 258:256-267

Stancic A, Jandl K, Hasenohrl C, Reichmann F, Marsche G, Schuligoi R, Heinemann A, Storr M, Schicho R (2015) The GPR55 antagonist CID16020046 protects against intestinal inflammation. Neurogastroenterol Motil 27:1432-1445

Storr MA, Keenan CM, Zhang H, Patel KD, Makriyannis A, Sharkey KA (2009) Activation of the cannabinoid 2 receptor (CB2) protects against experimental colitis. Inflamm Bowel Dis 15:1678-1685

Sumida H, Lu E, Chen H, Yang Q, Mackie K, Cyster JG (2017) GPR55 regulates intraepithelial lymphocyte migration dynamics and susceptibility to intestinal damage. Sci Immunol 2:https://doi. org/10.1126/sciimmunol.aao1135

Taschler U, Radner FP, Heier C, Schreiber R, Schweiger M, Schoiswohl G, Preiss-Landl K, Jaeger D, Reiter B, Koefeler HC, Wojciechowski J, Theussl C, Penninger JM, Lass A, Haemmerle G, Zechner R, Zimmermann R (2011) Monoglyceride lipase deficiency in mice impairs lipolysis and attenuates diet-induced insulin resistance. J Biol Chem 286:17467-17477

Wang F, Flanagan J, Su N, Wang LC, Bui S, Nielson A, Wu X, Vo HT, Ma XJ, Luo Y (2012) RNAscope: a novel in situ RNA analysis platform for formalin-fixed, paraffin-embedded tissues. J Mol Diagn 14:22-29

Wang L, Ray A, Jiang X, Wang JY, Basu S, Liu X, Qian T, He R, Dittel BN, Chu Y (2015) T regulatory cells and B cells cooperate to form a regulatory loop that maintains gut homeostasis and suppresses dextran sulfate sodium-induced colitis. Mucosal Immunol 8:1297-1312

Wehner S, Engel DR (2017) Resident macrophages in the healthy and inflamed intestinal muscularis externa. Pflugers Arch 469:541-552

Wright K, Rooney N, Feeney M, Tate J, Robertson D, Welham M, Ward S (2005) Differential expression of cannabinoid receptors in the human colon: cannabinoids promote epithelial wound healing. Gastroenterology 129:437-453

Wright KL, Duncan M, Sharkey KA (2008) Cannabinoid CB2 receptors in the gastrointestinal tract: a regulatory system in states of inflammation. Br J Pharmacol 153:263-270

Ziring D, Wei B, Velazquez P, Schrage M, Buckley NE, Braun J (2006) Formation of $\mathrm{B}$ and $\mathrm{T}$ cell subsets require the cannabinoid receptor CB2. Immunogenetics 58:714-725 